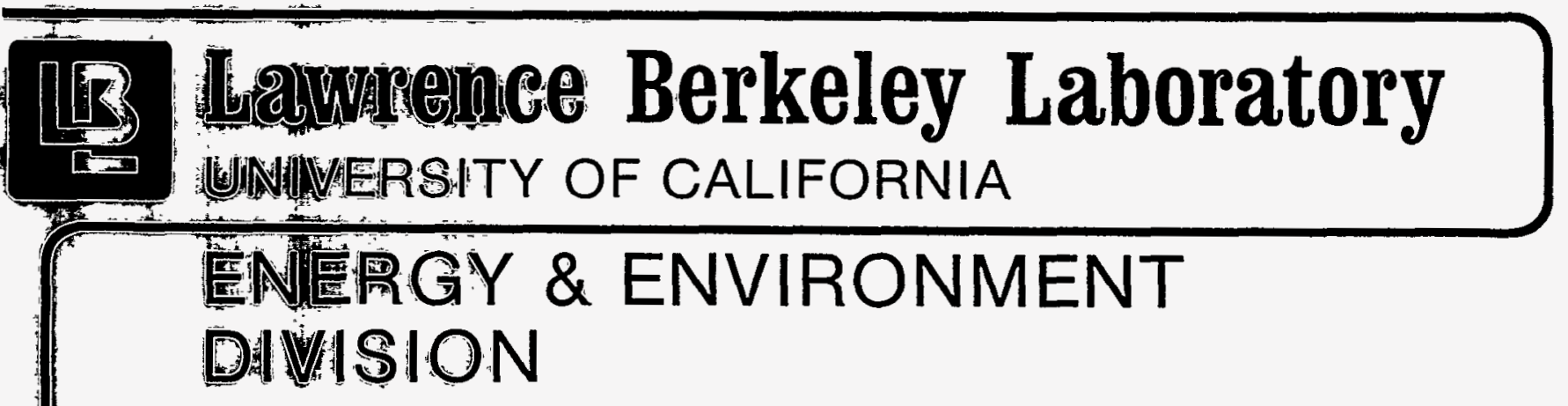

Magnetic Furorescent Ballasts: Market Data, Naranget Imperfections, and Policy Success

J.G. W. Sanstad, and L.J. Shown

December 1995

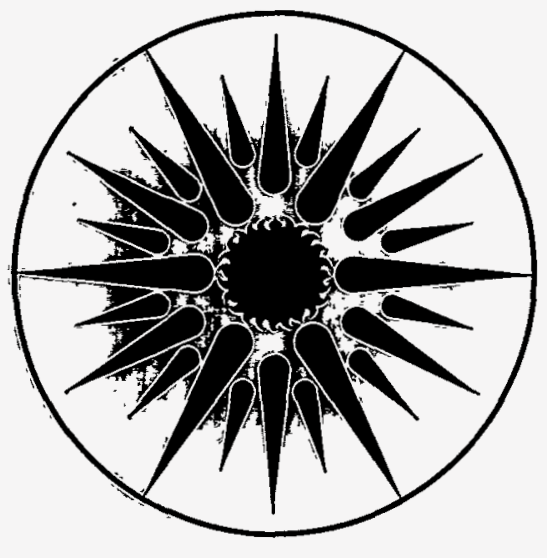

ENERGY

AND ENVIRONMENT DIVISION 


\section{DISCLAIMER}

This document was prepared as an account of work sponsored by the United States Government. While this document is believed to contain correct information, neither the United States Government nor any agency thereof, nor The Regents of the University of California, nor any of their employees, makes any warranty, express or implied, or assumes any legal responsibility for the accuracy, completeness, or usefulness of any information, apparatus, product, or process disclosed, or represents that its use would not infringe privately owned rights. Reference herein to any specific commercial product, process, or service by its trade name, trademark, manufacturer, or otherwise, does not necessarily constitute or imply its endorsement, recommendation, or favoring by the United States Government or any agency thereof, or The Regents of the University of California. The views and opinions of authors expressed herein do not necessarily state or reflect those of the United States Government or any agency thereof, or The Regents of the University of California.

Available to DOE and DOE Contractors from the Office of Scientific and Technical Information

P.O. Box 62, Oak Ridge, TN 37831

Prices available from (615) $576-8401$

Available to the public from the

National Technical Information Service

U.S. Department of Commerce

5285 Port Royal Road, Springfield, VA 22161

Ernest Orlando Lawrence Berkeley National Laboratory is an equal opportunity employer. 
LBL-37702

UC-1600

\title{
MAGNETIC FLUORESCENT BALLASTS: MARKET DATA, MARKET IMPERFECTIONS, AND POLICY SUCCESS
}

\author{
Jonathan G. Koomey, Alan H. Sanstad, and Leslie J. Shown
}

A shortened version of this report is forthcoming in Contemporary Economic Policy

\author{
$510 / 486-5974$ \\ 510/486-6996 FAX \\ Energy Analysis Program \\ Energy and Environment Division \\ Ernest Orlando Lawrence Berkeley National Laboratory \\ University of Califormia \\ Berkeley, CA 94720
}

December 1995

This work was supported by the Assistant Secretary for Energy Efficiency and Renewable Energy, Office of Building Technologies of the U.S. Department of Energy under Contract No. DE-AC03-76SF00098. 
Pecyeled Paper 


\begin{abstract}
1
Many economists have strongly questioned engineering-economic studies aimed at demonstrating anomalously slow diffusion of energy-efficient technology and the benefits of regulations to promote such technology. One argument against such studies is that standard techniques of engineering-economics are either inappropriate for or are routinely misapplied in assessing the performance of the market for energy efficiency.

This paper presents engineering-economic evidence on the diffusion of energy efficiency improvements that takes account of such critiques. We examine the engineering and economic characteristics of standard and energy-efficient magnetic ballasts for fluorescent lighting. Efficient magnetic ballasts represented an excellent investment for 99 percent of the commercial building floor stock, and a moderately good investment for 0.7 percent of the commercial floor stock. Still, these ballasts were only being adopted in the 1980s at a rate commensurate with the enactment of appliance efficiency standards in various states. In this case, there is solid empirical evidence for skepticism about the effectiveness of the market mechanism in promoting cost-effective energy efficiency improvements as well as evidence of the benefits of regulation to counteract this shortcoming.
\end{abstract}

${ }^{1}$ Keywords: Market failures, market imperfections, energy efficiency, fluorescent ballasts 


\section{TABLE OF CONTENTS}

I. INTRODUCTION............................................. 1

\section{ENGINEERING-ECONOMIC ANALYSIS OF ENERGY}

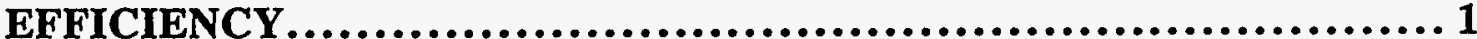

III. EFFICIENT MAGNETIC FLUORESCENT BALLASTS ...........4

1. The design of standard and efficient magnetic ballasts.........................4

2. The relationship between national market shares and standards...................4

3. Shipments and per unit costs of ballasts from market data..........................

4. Implied retail cost increase for efficient ballasts...............................

5. Operating hours and electricity prices .........................................11

6. Wattage savings per ballast .................................................11

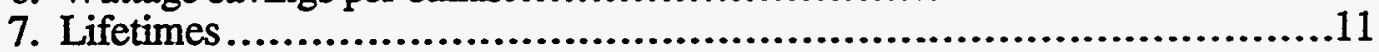

8. Economic characteristics of efficient magnetic ballasts............................12

IV. DISCUSSION............................................... 17

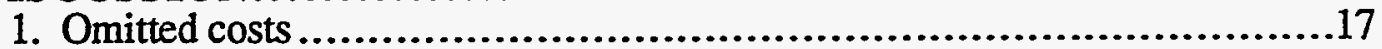

2. Correct parameter specification ..................................................

3. Time lags .................................................................18

4. Market imperfections .......................................................... 18

5. The importance of markups ..................................................19

6. Standards and ballast prices .................................................19

7. Standards and economic efficiency ...........................................19

8. Cost-effectiveness and policy context ......................................20

9. Implications for proposed standard requiring electronic ballasts..............20

V. FUTURE WORK.............................................. 20

1. Usage differences between $\mathrm{F} 40$ and $\mathrm{F} 96$ ballasts............................20

2. Economies of scale and the Progress Ratio ................................20

3. Market data on "Who buys what devices from whom?"...........................21

4. Market imperfections ............................................................21

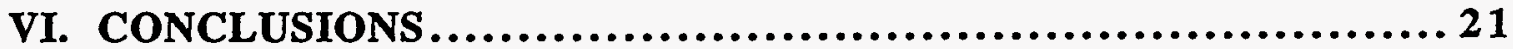

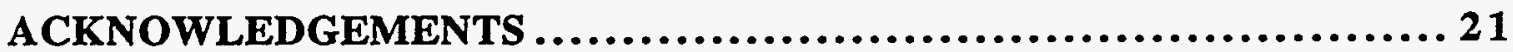

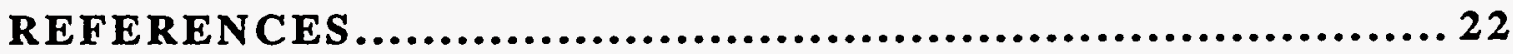

APPENDIX A: DERIVING STATE MARKET SHARES $\ldots \ldots \ldots \ldots \ldots \ldots 24$ 


\section{MAGNETIC FLUORESCENT BALLASTS: MARKET DATA, MARKET IMPERFECTIONS, AND POLICY SUCCESS}

\section{INTRODUCTION}

When Galileo first investigated the motion of falling bodies, he conducted what the Aristotelian clerics regarded as an heretical thought experiment. He imagined a world in which friction did not exist, and interpreted the results of his measurements of time, velocity, and acceleration in the context of this imaginary friction-free world. By eliminating the complicating effects of friction, Galileo was able to make great strides in what would come to be called the field of kinetics.

Galileo's innovation forms the essential basis of neoclassical methodology in economics. Conclusions derived from first principles are applied both to organize and to explain economic data, with "friction" or deviations from predicted outcomes typically accounted for in terms of statistical error or dismissed as noise. Neoclassical welfare economics does provide for the possibility of "imperfections" as a potential justification for intervention in otherwise unregulated markets. In debate over energy policies, however, there has been a notable reluctance on the part of many energy economists to seriously entertain the possibility of such imperfections related to technology diffusion, even in principle, in spite of a range of evidence that points to this conclusion.

In this paper, we focus on the engineering-economic methods commonly used by technologists to infer the existence of imperfections in the market for energy-efficiency and to justify policy interventions therein. We first discuss the use of such methods for analyzing the diffusion of energy-efficiency improvements; we address both their appropriateness and the conditions required for their correct application. Against this background, we proceed to discuss the engineering and economic characteristics of standard and energy-efficient magnetic ballasts for fluorescent lighting. We conclude that the evidence associated with this technology - in particular, under-adoption of the more efficient ballast - provides strong evidence for the existence of economic inefficiency in the market for energy efficiency. We go on to argue that the imposition of minimum efficiency standards for ballasts thus resulted in net economic benefits to users of the technology and to society. While our analysis does not allow us to state unambigously the exact nature of the market imperfections or anomalies inhibiting adoption of the more efficient ballasts, we list several possibilities raised in recent research on this subject. We close with a summary and suggestions for further research.

\section{ENGINEERING-ECONOMIC ANALYSIS OF ENERGY EFFICIENCY}

Among both technologists and economists, investment in energy efficiency is typically viewed as involving a trade-off between higher initial costs and lower operating costs for incremental increases in energy efficiency. Thus, the familiar concept of the "internal rateof-return" (IRR) for such incremental investments is an appropriate focal point for both modeling and measurement. In particular, the notion of an energy-efficiency "gap"widespread under-investment in energy-efficient technology - can be precisely expressed by the statement that many such investments are systematically foregone despite having IRRs that substantially exceed typical rates of return available in capital markets. 
Many technologists have used engineering-economic calculations to estimate the cost effectiveness of energy-efficient options for specific end-uses, and then argued for the implementation of government policies and utility programs aimed at promoting such ostensibly cost-effective options. As with any other approach to quantitative modeling, these methods have limitations and can be (and have been) misused. In the face of robust evidence of under-investment in energy efficiency, however, some economists have argued more strongly that conventional discounted cash-flow models are theoretically inadequate for studying energy-efficiency investments, and must be supplanted by more ostensibly sophisticated techniques that take account of risk and uncertainty (Hassett and Metcalf 1993, Metcalf 1994, Sutherland 1991). However, Stoft et al. (1993), Sanstad et al. (1995), and Howarth and Sanstad (1995) demonstrate that the quantitative implications of these theoretical arguments do not fully explain the high implicit discount rates repeatedly observed in energy-efficiency investments.

The failure of more "sophisticated" attempts to explain the "gap" does not, of course, imply that standard engineering-economic methods cannot be and have not been subject to misapplication. We next describe a series of pitfalls often ascribed to their use. The aim of this discussion is to delineate the conditions under which engineering-economic computations can contribute productively to discussions about economic efficiency, technology choice, and the existence of market imperfections. Our focus, specifically, is the application to energy-efficiency investments of the standard model of discounted cashflow analysis under conditions of certainty.

We first recall that the engineering-economic evaluation of a potential investment in energy efficiency, specifically the computation of the IRR, is independent of the question of what discount rate decision-makers "should" apply to such investments (i.e., to account for the cost of capital and the perceived riskiness of investment options). This approach allows us, in the first instance, to separate the evaluation of the rate of return of efficiency options from the problem of specifying discount rates.

Our initial focus is on the factors that might corrupt the measurement of rates-of-return available from energy-efficiency investments. We single out three such factors that have figured prominently in the debate over energy efficiency: (1) omitted costs, (2) incorrect parameter specification or aggregation bias in the calculations, and (3) time lags arising from normal patterns of technology diffusion (Koomey and Sanstad 1994). Each of these possibilities is described below:

Omitted costs ${ }^{2}$ : There are several categories of omitted costs that may either result in overestimation of the benefits of energy-efficiency investment or simply call into question the interpretability of such estimation. First, there is the potential for a reduced level of energy service or amenity (e.g., quality of lighting or temperature and comfort levels associated with heating systems). Second, there may be irreducible private costs (such as the inconvenience associated with installation of the efficient equipment). There may also be costs for consumers to identify the more efficient technology and verify its effectiveness. Finally, other costs may not be included in the calculations, including sales, income, and property taxes and additional maintenance costs for the efficient measure.

Parameter specification and aggregation bias: The input parameters in each analysis must capture the range of possible physical situations and usage characteristics existing

\footnotetext{
2In previous discussions of this framework (Koomey and Sanstad 1994), the term "hidden costs" was used for this category. We have changed this terminology to be more precise.
} 
throughout the economy. Calculations are often based on engineering calculations using typical buildings or appliances - these typical buildings may submerge details about the distribution of characteristics affecting cost-effectiveness (e.g., operating hours of buildings can vary widely). Engineering calculations may overstate the benefits of energy efficiency by calculating energy savings with respect to a base case building or device that is less efficient than currently designed new buildings or new devices.

Time lags: New technologies take time to reach the market and to be understood and accepted by the design community (the effort needed to learn about new technologies is another omitted cost that is likely to be greatest when these technologies are introduced rapidly). In some cases, manufacturers may need years to scale up production of a new technology. This aspect of technology diffusion raises analytical and empirical problems that are difficult to address in the standard engineering-economic framework. For purposes of using this methodology, it is therefore important to concentrate on technologies that are readily available, and whose characteristics minimize the barriers to diffusion.

Suppose that, in the analysis of energy efficiency in a particular end-use, the above factors have been accounted for but we still find that a "high" rate-of-return to energy efficiency investment is being passed up in the market place. For policy analysis, the problem is then to precisely define what is meant by "high." Specifically, if we can show that the rate-ofreturn exceeds that which a rational investor should demand from such an investment, we can then conclude that there is a potential re-allocation of resources - from fuel to capital inputs-that would allow the same consumption of energy services, but at lower cost. This conclusion is equivalent to saying that a market imperfection is preventing this re-allocation from taking place.

At what threshold for the IRR can we pursue this line of reasoning? Technologists are commonly criticized for invoking a "social discount rate" or weighted corporate cost-ofcapital in the neighborhood of 6 percent real as a threshold (e.g., Nichols (1994)), even though that cost of capital is typical for utility supply-side investments against which the demand-side investments compete. A common rule-of-thumb is to regard 20 percent real as an approximate upper bound for a "reasonable" hurdle rate, taking into account measurement problems, variation in user-specific opportunity costs, and so forth. ${ }^{3}$

In the following section, we report on calculations that use both 6 and 20 percent as benchmarks and demonstrate that for the vast majority of commercial sector floor area, IRRs for investments in efficient ballasts substantially exceed 20 percent. Reasoning as above, we thus demonstrate the presence of one or more market imperfections affecting this technology.

The precise nature of such imperfections is currently the focus of intense debate, and a detailed discussion is beyond the scope of this paper. We note, however, that economists, technologists, and other analysts are beginning to agree that imperfections in markets for energy-efficiency, where they are present, most likely stem from imperfect or asymmetric information, transaction costs, and related factors. ${ }^{4}$ We return briefly to this point following our empirical discussion.

${ }^{3}$ Metcalf and Rosenthal (1993) calculate that the rational hurdle rate for fluorescent lighting upgrades should be 13.9 percent real.

${ }^{4}$ See Huntington et al. (1994), and the papers therein, for in-depth examinations of these issues from a range of disciplinary viewpoints. 


\section{EFFICIENT MAGNETIC FLUORESCENT BALLASTS}

In this section, we examine two types of fluorescent lighting technology that have substantially different energy-consumption characteristics. We begin with a brief description of both standard and energy-efficient magnetic ballasts. We then summarize the state and federal policies that affected ballast production between 1983 and 1990. Finally, we use historical market data to assess the cost effectiveness of efficient magnetic ballasts.

\section{The design of standard and efficient magnetic ballasts}

The operation of a fluorescent lamp requires a transformer, or "ballast," to provide the high voltage necessary to start the lamp and also to limit the flow of electrical current to the lamp while it is operating. For decades, almost all fluorescent lamp ballasts were standard magnetic ballasts ("standard ballasts"). Standard ballasts operate at an input frequency of 60 hertz $(\mathrm{Hz})$. Typically, a standard ballast has a relatively small core made of low-grade steel and coil windings made of aluminum wire.

In 1976, manufacturers introduced a more energy-efficient magnetic ballast to the market. Efficient ballasts ${ }^{5}$ use the same core-coil design as standard ballasts, but have a number of design features that reduce the thermal energy losses associated with an alternating magnetic field. These design features include larger cores made of higher-grade steel; reduced insulation thickness; coils of copper wire (rather than aluminum); and higherdensity coil windings. In addition, efficient ballasts have longer lifetimes than standard ballasts. In terms of size and use characteristics, the efficient ballast was an identical replacement for the standard ballast. ${ }^{6}$

In the mid to late 1980 s, electronic ballasts (which are distinct from efficient magnetic ballasts) had garnered a few percent market share. They used solid-state circuits to modulate current flow, and offered greater energy efficiency than did the efficient magnetic ballasts. When first introduced, they also cost substantially more than comparable magnetic ballasts. As the price dropped over time and as utilities promoted their use, electronic ballasts captured more of the market (see below).

\section{The relationship between national market shares and standards}

In 1977, efficient magnetic ballasts accounted for less than one percent of ballast sales. In testimony before the U.S. House of Representatives in 1988, the vice president of Advanced Transformer Company (which manufactured approximately one-third of the ballasts produced in the U.S. in 1990) asserted that the ballast industry had actively promoted efficient ballasts, but consumer acceptance was remarkably slow. He stated that efficient ballasts represented only 10 to 15 percent of those sold in 1980; by 1988, they represented about one-third of all ballasts sold. ${ }^{7}$ In spite of this increase in market share, he said in his testimony that "it continues to surprise us that it has been so difficult to sell

\footnotetext{
5In this paper, the term "efficient ballast" will be used to mean "efficient magnetic ballast".

${ }^{6}$ In this respect the ballasts are distinguished from early compact fluorescent units for residential use, which had color temperature and fixture geometry characteristics differing substantially from conventional incandescent bulbs.
}

${ }^{7}$ If taken literally, this statement implies that efficient magnetic ballasts had a $34 \%$ share of all magnetic ballasts (because there were 1.1 million electronic ballasts sold in 1988). 
such a bargain ... we have observed that the momentum of acceptance of energy-saving ballasts is tapering off. We now believe that it may be difficult to even reach 50 percent market penetration" (Freegard 1988).

Because of the slow market acceptance of this technology after its introduction, California adopted an energy-efficiency standard for fluorescent lamp ballasts in 1982. The standard affected approximately $90 \%$ of ballasts manufactured at that time and banned the manufacture and sale of standard magnetic ballasts within the state of $\mathrm{CA}$. The CA standard became effective in 1983 (CEC 1981, CEC 1982).

Over the next five years, four more states followed CA's lead and adopted efficiency standards that banned the manufacture and sale of standard magnetic ballasts. Standards for New York, Massachusetts, Connecticut, and Florida became effective in 1986, 1988, 1988 , and 1989, respectively. By 1988, approximately one-third of magnetic ballasts sold in the U.S. were energy efficient.

A federal standard for fluorescent ballasts was added to the National Appliance Energy Conservation Act in 1988 and became effective in January 1990. The federal standard was introduced to avoid the complications associated with different states having different standards and because it appeared that the demand for this technology had leveled off. Representatives of the ballast industry spoke in favor of the standard and it passed by an overwhelming margin. ${ }^{8}$

The changes in market shares for efficient ballasts are illustrated in Figure 1. The estimated market shares from the Congressional testimony in 1980 and 1988 are shown as large black circles. The years when the state standards took effect are labeled with arrows. In Appendix A, we calculate the percentage of ballast sales attributable to each state, using information about the distribution of population, of non-residential construction contracts, and of saturations of efficient ballasts before the standards went into place. These percentages for California (9.2\%), New York (6.4\%), Massachusetts $(2.2 \%)$, and Connecticut $(1.2 \%)$ are added to the 1980 market share $(12.5 \%)$ at the appropriate dates. The result is a market share in 1988 of $31.5 \%$, or about one-third.

The growth in efficient ballast market shares cited in the testimony is almost exactly accounted for by the states that imposed standards. This striking coincidence of market shares, combined with the manufacturers' testimony at the 1988 hearings, strongly suggests that the growth in shares over this eight year period would not have occurred without the standards.

${ }^{8}$ The regulation governing the sale and manufacture of energy-efficient ballasts can be found in Title 10 Part 430 Section $430.32(\mathrm{~m})$ of the Code of Federal Regulations. It states that manufacture of standard magnetic ballasts is prohibited after January 1,1990 and sales of inefficient ballasts or the incorporation of those ballasts into luminaires is prohibited after April 1, 1991. Dimming ballasts, ballasts designed for operation at zero degrees $F$ or less and residential ballasts of less than 0.9 power factor are exempt. Any substandard ballast manufactured before January 1, 1990 could be sold by the manufacturer until April 1, 1990 . Substandard ballasts in distributor inventory could be sold after April 1, 1991 if they were sold as replacement units; they could not be sold to a luminaire manufacturer. 
Figure 1: Efficient magnetic ballasts as a percentage of total magnetic ballasts

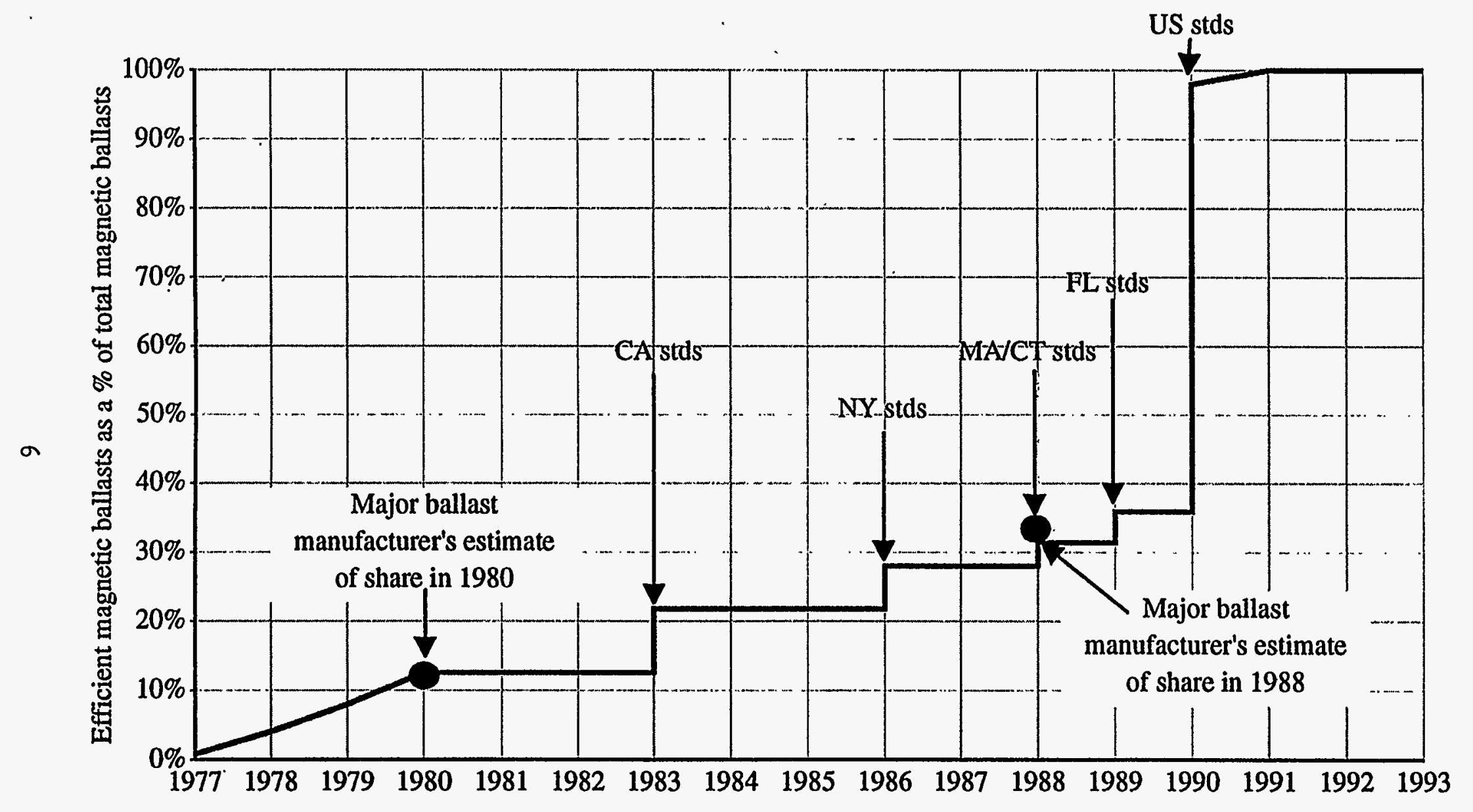




\section{Shipments and per unit costs of ballasts from market data}

Table 1 summarizes Census data on domestic shipments of US ballasts to the commercial sector, taken from the Department of Commerce MQ36C data series. ${ }^{9}$ Shipments are split into F40 magnetic ballasts, F96 magnetic ballasts, and electronic ballasts. Costs per unit are derived by dividing the Census-reported value of shipments by the number of shipments. All costs are adjusted to 1993 dollars.

Costs per unit show a steady decline from about 1980 to the late 1980s. From 1989 to 1990 there is a significant jump in the price of both types of magnetic ballasts, but costs resume their downward trend after 1990. By 1993, costs per unit for F40 ballasts had declined in real terms to levels below those recorded since 1977, and for F96 ballasts had declined to mid-to-late 1980s levels. Electronic ballast costs per unit start declining after 1986, go up about $11 \%$ in 1989, and continue their rapid downward trend after that. Real costs per ballast for electronic ballasts decline by about a factor of two between 1986 and 1993, reflecting the rapid technological progress common in solid-state products.

The market shares of efficient ballasts from Figure 1 and the shipments of domestic ballasts from Table 1 can be used to create Figure 2, which shows domestic shipments to the commercial sector split into electronic ballasts, efficient magnetic ballasts, and inefficient magnetic ballasts. Figure 2 demonstrates the dramatic transformation wrought on the market by the Federal standards.

\section{Implied retail cost increase for efficient ballasts}

We can use the change in costs per unit from 1989 to 1990 to estimate the implied cost premium per ballast for efficient magnetic ballasts over their inefficient counterparts. ${ }^{10}$ This calculation also requires knowing the percentage of ballasts that were efficient in 1989 (35.9 percent, from Figure 1). We assume, for ease of calculation, that the percentage of ballasts that were efficient in 1990 was 100 percent, even though there was probably a small percentage of ballasts left over from 1989 inventories in the 1990 shipments.

To convert the per unit costs implied in the Census data to retail costs, it is necessary to apply a markup. The value of shipments reported contains a mixture of paths by which manufacturer sales make their way to the retail market, and few manufacturer sales are directly to consumers. Table 2 derives approximate markups that we apply to the cost changes from 1989 to 1990 in Table 1, using data from the Lighting Research Institute (LRI 1995a) and Logan (1995). This markup increases the costs per unit derived from the Census data by about a factor of 2 , implying a retail cost premium from the Census data for

\footnotetext{
${ }^{9}$ The Census data omits imports from their reports, presumably because it is harder to collect data from foreign firms. Low power-factor ballasts are omitted from our shipments data because they are not typically used in the commercial sector (they are used mainly in residential shop lights and low wattage switch-start luminaires). We also excluded $1500 \mathrm{MA}$ ballasts (which are mainly used in the industrial sector), and miscellaneous high power-factor switch-start ballasts (which are used in a variety of specialty applications). Special thanks to Al Gough of the Lighting Research Institute for compiling the data and helping us correctly allocate ballast sales to the appropriate categories.
}

10This approach is of necessity an approximation. There were other possible changes in the market for ballasts that may have influenced the per-ballast cost change from 1989 to 1990, but the most important effect was that of the ballast standards. 
Table 1: Shipments of domestically-produced ballasts to the US commercial sector (millions) and costs per unit (1993\$/unit)

\begin{tabular}{|c|c|c|c|c|c|c|c|c|}
\hline & \multicolumn{2}{|c|}{ F40 + other magnetic ballasts } & \multicolumn{2}{|c|}{ F96 magnetic ballasts } & \multicolumn{2}{|c|}{ Electronic ballasts } & \multicolumn{2}{|c|}{ Total domestic comml ballasts } \\
\hline & $\begin{array}{c}\text { Shipments } \\
\text { Millions }\end{array}$ & $\begin{array}{c}\text { Costs } \\
1993 \$ / \text { unit }\end{array}$ & $\begin{array}{l}\text { Shipments } \\
\text { Millions }\end{array}$ & $\begin{array}{c}\text { Costs } \\
\text { 1993\$/unit }\end{array}$ & $\begin{array}{c}\text { Shipments } \\
\text { Millions }\end{array}$ & $\begin{array}{c}\text { Costs } \\
\text { 1993\$/unit }\end{array}$ & $\begin{array}{c}\text { Shipments } \\
\text { Millions }\end{array}$ & $\begin{array}{c}\text { Costs } \\
1993 \$ / \text { unit }\end{array}$ \\
\hline 1977 & 29.4 & 7.86 & 9.7 & 16.04 & & & 39.1 & 9.89 \\
\hline 1978 & 30.3 & 7.73 & 9.7 & 15.64 & & & 40.1 & 9.65 \\
\hline 1979 & 37.7 & 8.49 & 11.7 & 16.43 & & & 49.4 & 10.36 \\
\hline 1980 & 33.0 & 8.49 & 10.8 & 17.17 & & & 43.8 & 10.64 \\
\hline 1981 & 31.5 & 8.35 & 10.1 & 16.94 & & . & 41.6 & 10.43 \\
\hline 1982 & 29.3 & 8.41 & 9.2 & 16.87 & & & 38.6 & 10.44 \\
\hline 1983 & 31.0 & 8.03 & 10.7 & 16.30 & & & 41.7 & 10.15 \\
\hline 1984 & 37.0 & 7.78 & 11.5 & 16.66 & & & 48.6 & 9.89 \\
\hline 1985 & 38.9 & 7.36 & 11.9 & 15.72 & & & 50.7 & 9.31 \\
\hline 1986 & 39.6 & 7.21 & 11.6 & 14.91 & 0.4 & 37.65 & 51.6 & 9.19 \\
\hline 1987 & 40.4 & 7.16 & 13.2 & 14.02 & 0.7 & 33.61 & 54.3 & 9.18 \\
\hline 1988 & 41.3 & 7.11 & 14.7 & 13.12 & 1.1 & 29.58 & 57.1 & 9.08 \\
\hline 1989 & 43.1 & 7.08 & 14.3 & 13.58 & 1.4 & 32.82 & 58.9 & 9.28 \\
\hline 1990 & 42.6 & 7.79 & 12.4 & 16.24 & 3.0 & 25.79 & 58.0 & 10.53 \\
\hline 1991 & 42.5 & 7.26 & 12.1 & 15.27 & 8.3 & 23.05 & 63.0 & 10.89 \\
\hline 1992 & 41.6 & 6.88 & 12.8 & 14.23 & 13.3 & 21.29 & 67.7 & 11.10 \\
\hline 1993 & 40.1 & 6.47 & 12.6 & 13.93 & 24.5 & 18.23 & 77.2 & 11.42 \\
\hline
\end{tabular}

(1) Costs per unit derived from value of sales divided by shipments, adjusted to $1993 \$$ using the fixed-weight price index for consumer expenditures from Census 1994, Table 756, p. 500.

(2) 1987 data are omitted from the Department of Commerce reports (Census MQ36C). We interpolated between 1986 and 1988 data to estimate 1987 values.

(3) F40 + other magnetic ballasts are all rapid-start.

(4) Low power factor ballasts (shipments of 28.2 million in 1993), $1500 \mathrm{MA}$ ballasts ( 0.3 million in 1993) and all other high power factor ballasts (1.4 million in 1993) are omitted because they also are not typically used in the commercial sector. Slimline-other power factor corrected ballasts (1.34 million shipments in 1993) are included under F96 magnetic ballasts.

(5) F40 ballasts generally power 4 foot lamps and F96 ballasts power 8 foot lamps. 


\section{Figure 2: Shipments of domestically-produced ballasts to the US commercial sector}

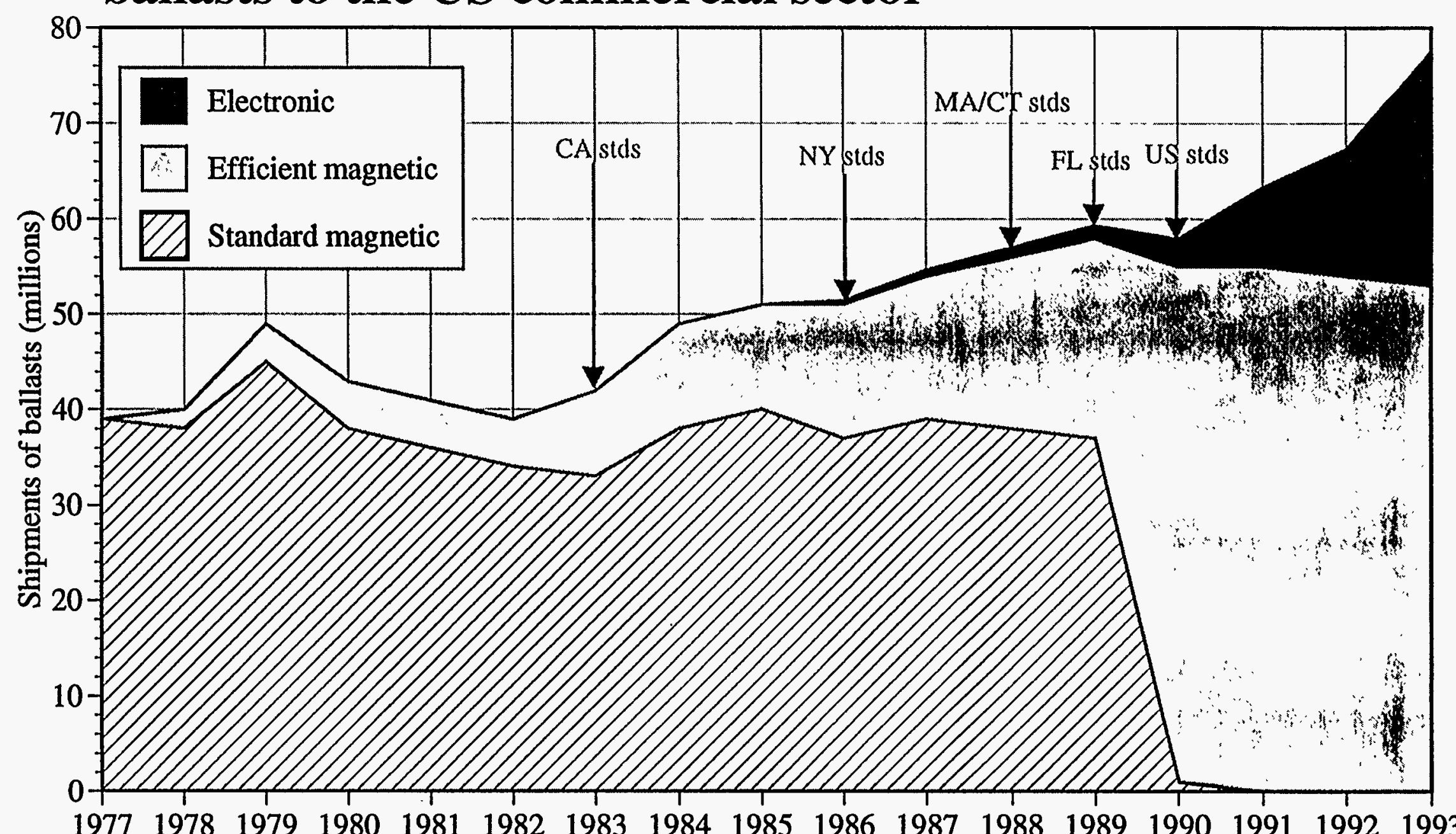

(1) Various efficiency standards prevented the standard magnetic ballast from being sold.

(2) Imports not reported in the Census data 
Table 2: Markups for calculating retail costs of ballasts to the commercial sector

\begin{tabular}{|l|cc|cc|}
\hline Path to retail sale & $\begin{array}{c}\text { F40 magnetic } \\
\text { Estimate } \\
\% \text { of sales }\end{array}$ & $\begin{array}{c}\text { Estimated } \\
\text { markup } \\
\text { factor to } \\
\text { retail }\end{array}$ & $\begin{array}{c}\text { F96 magnetic } \\
\text { Estimate } \\
\% \text { of sales }\end{array}$ & $\begin{array}{c}\text { Estimated } \\
\text { markup } \\
\text { factor to } \\
\text { retail }\end{array}$ \\
\hline Original equipment manufacturer (OEMs) & $63 \%$ & 1.80 & $63 \%$ & 1.80 \\
Lighting maintenance companies (LMCs) & $5 \%$ & 1.20 & $5 \%$ & 1.20 \\
Electrical distributors (EDs) & $32 \%$ & 3.50 & $32 \%$ & 2.00 \\
\hline Weighted average markup & & 2.31 & & 1.83 \\
\hline
\end{tabular}

(1) The distribution of shipments by path to retail sale as shown above is taken from Lighting Research Institute estimates (LRI 1995).

(2) Original equipment manufacturers buy ballasts from manufacturers and install them in fixtures. The complete luminaire is then sold to customers.

Lighting maintenance companies purchase ballasts and/or luminaires and install complete lighting system retrofits (both efficiency upgrades and replacement in-kind) for building owners or tenants.

Electrical distributors buy ballasts from the manufacturers and sell to end-users when

individual ballasts fail. Thus, the markups for this channel are higher than for the other two channels.

(3) Markups for OEMs and LMCs taken from LRI estimates (LRI 1995).

Markups for F40s by EDs estimated to be 3.5, based on Logan 1995 (personal communication).

Markups by EDs on F96 ballasts estimated to be 2.0 because most F96 lamps are purchased in

substantial quantities by large commercial customers who have their own electricians install them, hence the lower markup (Logan 1995). 
the efficient magnetic ballast of about $\$ 2.6 /$ unit (1993\$) for the F40 ballasts and about $\$ 7.6 /$ unit for the F96 ballasts.

\section{Operating hours and electricity prices}

Two key parameters for any cost-effectiveness calculation are the hours of operation and the appropriate electricity prices. Many previous analyses have used averages for these parameters based on estimates of typical building characteristics. For this analysis, we rely on a survey of commercial building characteristics conducted by the US Department of Energy's Energy Information Administration. The Commercial Buildings Energy Consumption Survey or CBECS (US DOE 1991a, US DOE 1991b) contains survey data collected from a statistically representative sample of more than 5500 commercial buildings throughout the US.

We began with the electronic CBECS sample, and extracted operating hours per week, floor area per building, total electric consumption, total electric expenditures and other relevant parameters for our analysis. We then dropped out about nine percent of the records. Most (about 80 percent) of these were dropped because the records did not have data in the field for "percent of lights that are fluorescent". The rest were dropped because they had no data for weekly operating hours or total electricity consumption (needed to derive average electricity prices), or were not operated during the past twelve months. Survey records for more than 5000 buildings remained after we cleaned the data.

We calculated implied electricity prices by dividing total electric expenditures by total electricity consumption. ${ }^{11}$ We then dropped out about 80 records that had implied electricity prices in 1989 dollars of greater than $\$ 0.20 / \mathrm{kWh}$ because such high prices are likely the result of data problems (the US average price was around $\$ 0.07 / \mathrm{kWh}$ in 1989). The weighted average prices from CBECS were then uniformly scaled down by 10 percent to make the CBECS average reflect the overall US average price in 1989, from US DOE (1991c). We adjusted the prices to 1993 dollars using the fixed-weight price index for consumer expenditures (Census 1994).

Our calculations of cost effectiveness assume that electricity prices remain constant. This assumption reflects the perspective of forecasters in the late 1980s and early 1990s, who expected little change in real electricity prices over the following ten to fifteen years (US DOE 1989).

\section{Wattage savings per ballast}

Estimated savings per ballast are 10 watts for the F40 ballasts and 15 watts for the F96 ballasts (Freegard 1988). We use the savings from two-lamp ballasts, which comprise the overwhelming majority of ballasts sold in the US.

\section{Lifetimes}

Ballast lifetimes are 33,000 hours for F40 ballasts and 36,000 hours for F96 ballasts, taken from surveys of ballast manufacturers, luminaire manufacturers, and lighting management companies with vast experience in replacing ballasts (LRI 1995b). The average lifetime

\footnotetext{
${ }^{11}$ Our calculation of electricity price from the CBECS utility billing data implicitly includes the demand charges common in commercial buildings.
} 
implied by these figures and the CBECS hourly usage distribution is eight to nine years. For buildings where the implied lifetime would exceed 20 years (very low usage buildings) we arbitrarily assigned lifetimes of 20 years.

We use the same lifetimes for standard and efficient ballasts, even though Freegard (1988) states that the efficient ballasts last "twice as long" as the inefficient type. This improved lifetime is mainly the result of lower heat dissipation inside the ballast. The longer lifetime of the efficient ballasts would improve the cost effectiveness of these devices, though, as we discuss below, the internal rate of return calculations are somewhat insensitive to the assumed lifetime.

\section{Economic characteristics of efficient magnetic ballasts}

We show two measures of cost-effectiveness in Table 3: cost of conserved energy $(\$ / \mathrm{kWh})$ and the real internal rate of return (IRR) for an investor choosing to purchase the efficient magnetic ballast. We begin by sorting the 5000 remaining CBECS buildings from lowest to highest operating hours. We then combine the data into three operating hour bins (low hours, medium hours, high hours). The first bin comprises the lowest 30 percent of the buildings, the second bin comprises the middle 40 percent of the buildings, and the third bin comprises the highest 30 percent of the buildings. As shown in Table 3, buildings with higher operating hours generally have lower electricity prices than buildings with lower operating hours, mainly because intensively-operated larger buildings are given favorable utility rates.

The cost of conserved energy (CCE) ${ }^{12}$ using a 6 percent real discount rate is at least 70 percent lower than the price of electricity in all cases. Using a 20 percent real discount rate, the $\mathrm{CCE}$ is at least 40 percent lower than the electricity price for each building cohort. The IRRs for our building cohorts using the appropriate operating hours and electricity prices range from almost 40 percent real for F96 ballasts in the low operating hours case to about 200 percent real in the high operating hours case for F40 ballasts (Figure 3). By either of these two measures, the choice of efficient magnetic ballasts is quite cost effective.

It can be argued, however, that this analysis is still too aggregated to capture the full range of possibilities. We therefore show Table 4, which breaks the bins down into ten percent increments (the first bin contains the ten percent of the buildings with the lowest operating hours, etc). Even for the least favorable bin (the lowest operating hours case for F96 ballasts) the IRR for purchasing the efficient ballast is 31 percent real. The disaggregation also shows much larger IRRs for the highest usage bin compared to the more aggregated data in Table 3.

Finally, we calculate the percent of commercial sector floor area attributable to different IRRs. We sorted the records by IRR for F40 and F96 ballasts and combined the records into bins titled "IRR $<6$ percent real", " 6 percent $\leq$ IRR $<20$ percent real", and "IRR $\geq 20$ percent real". This calculation demonstrates that the overwhelming majority of the commercial sector floor area ( 99 percent) is associated with IRRs of greater than 20 percent real. About 0.7 percent of the floor area is associated with IRRs of between 6 percent and 20 percent. Only 0.3 percent of the floor area is in the bin that is clearly not cost effective.

${ }^{12}$ The CCE is calculated by annualizing the incremental capital cost of the efficiency measure and dividing by the annual energy savings (see Koomey et al. (1991) for details). 
Table 3: Cost effectiveness of efficient magnetic ballasts in US commercial buildings in 1989, based on market data

\begin{tabular}{|c|c|c|c|c|c|}
\hline & & $\begin{array}{l}\text { \%o of comml } \\
\text { floor area } \\
\text { represented }\end{array}$ & $\begin{array}{c}F 40 \\
\text { Ballast }\end{array}$ & $\begin{array}{c}F 96 \\
\text { Ballast }\end{array}$ & $\begin{array}{l}\text { Sales Wtd } \\
\text { average }\end{array}$ \\
\hline$\Delta$ in avg mag. ballast cost $1989-90$ & 1993\$/ballast & & 0.71 & 2.66 & 1.15 \\
\hline Incremental cost of efficient ballasts & 1993\$/ballast & & 2.58 & 7.62 & 3.97 \\
\hline \multicolumn{6}{|l|}{ Operating hours } \\
\hline High usage & Hours/year & $34 \%$ & 6837 & 6837 & 6837 \\
\hline Average usage & Hours/year & $40 \%$ & 3104 & 3104 & 3104 \\
\hline Low usage & Hours/year & $26 \%$ & 2126 & 2126 & 2126 \\
\hline \multicolumn{6}{|l|}{ Operating lifetime } \\
\hline High usage & years & $34 \%$ & 5 & 5 & 5 \\
\hline Average usage & years & $40 \%$ & 11 & 12 & 11 \\
\hline Low usage & years & $26 \%$ & 16 & 17 & 16 \\
\hline Savings rel. to inefficient ballast & W/ballast & & 10 & 15 & 11.1 \\
\hline \multicolumn{6}{|c|}{ Savings rel. to inefficient ballast } \\
\hline High usage & $\mathrm{kWh} /$ ballast/year & $34 \%$ & 68 & 103 & 76 \\
\hline Average usage & $\mathrm{kWh} / \mathrm{ballast} / \mathrm{year}$ & $40 \%$ & 31 & 47 & 35 \\
\hline Low usage & $\mathrm{kWh} /$ ballast/year & $26 \%$ & 21 & 32 & 24 \\
\hline \multicolumn{6}{|l|}{ Annualized cost at $6 \%$ real } \\
\hline High usage & 1993 ф/kWh & $34 \%$ & 0.9 & 1.7 & 1.1 \\
\hline Average usage & $1993 \phi / \mathrm{kWh}$ & $40 \%$ & 1.1 & 2.0 & 1.3 \\
\hline Low usage & $1993 ф / \mathrm{kWh}$ & $26 \%$ & 1.2 & 2.3 & 1.5 \\
\hline \multicolumn{6}{|l|}{ Annualized cost at $20 \%$ real } \\
\hline High usage & 1993 c/kWh & $34 \%$ & 1.3 & 2.4 & 1.5 \\
\hline Average usage & $1993 \phi / \mathrm{kWh}$ & $40 \%$ & 1.9 & 3.7 & 2.3 \\
\hline Low usage & $1993 \mathrm{c} / \mathrm{kWh}$ & $26 \%$ & 2.6 & 5.0 & 3.1 \\
\hline \multicolumn{6}{|l|}{$\begin{array}{l}\text { Metered electricity price in } 1989 \\
\text { for buildings in the CBECS sample }\end{array}$} \\
\hline High usage & $1993 \phi / \mathrm{kWh}$ & $34 \%$ & 7.5 & 7.5 & 7.5 \\
\hline Average usage & $1993 \not / k W h$ & $40 \%$ & 8.7 & 8.7 & 8.7 \\
\hline Low usage & $1993 \phi / \mathrm{kWh}$ & $26 \%$ & 8.9 & 8.9 & 8.9 \\
\hline \multicolumn{6}{|l|}{ IRR for efficient core-coil ballasts } \\
\hline High usage & \%/year & $34 \%$ & $199 \%$ & $98 \%$ & $176 \%$ \\
\hline Average usage & \%/year & $40 \%$ & $104 \%$ & $53 \%$ & $93 \%$ \\
\hline Low usage & \%/year & $26 \%$ & $73 \%$ & $37 \%$ & $65 \%$ \\
\hline
\end{tabular}




\section{FOOTNOTES TO TABLE 3}

(1) IRR and annualized costs calculated assuming 33,000 hour lifetime for F40s, 36,000 hour lifetime for F96s, and constant real electricity prices (lifetimes from a survey by LRI 1995).

Annualized costs equal the Capital Recovery Factor times the incremental capital cost of the efficient ballas (2) Change in costs 1989 to 1990 taken directly from Table 1. Incremental costs for efficient ballasts reflect markups from Table 2 and the fact that not all ballasts sold in 1989 were efficient. Saturation of efficient magnetic ballasts is $35.9 \%$ in 1989.

(3) Commercial building operating hours estimated from US DOE 1991a. "Low Usage" buildings are the $30 \%$ of the buildings with the lowest operating hours, and "High Usage" buildings are the $30 \%$ of the buildings with highest operating hours. "Medium Usage" buildings are the median $40 \%$ of the buildings. Low Usage buildings are generally smaller in size than High Usage buildings, so the percentage of floor area attributable to Low Usage Buildings is less than $30 \%$, and for High Usage is greater than $30 \%$.

(4) Commercial sector electricity prices are the weighted averages across all buildings in each usage bin, taken from the CBECS 1989 electronic sample (US DOE 1991b), and scaled downward by $10 \%$ to make the overall average reflect average 1989 prices to the US commercial sector from US DOE (1991c) (5) Sales of F40 ballasts were $77 \%$ of total magnetic ballasts in 1990 , and F96 were $23 \%$. 
Figure 3: Real internal rates of return for purchasing efficient magnetic ballasts in the US commercial sector (circa 1989), based on market data

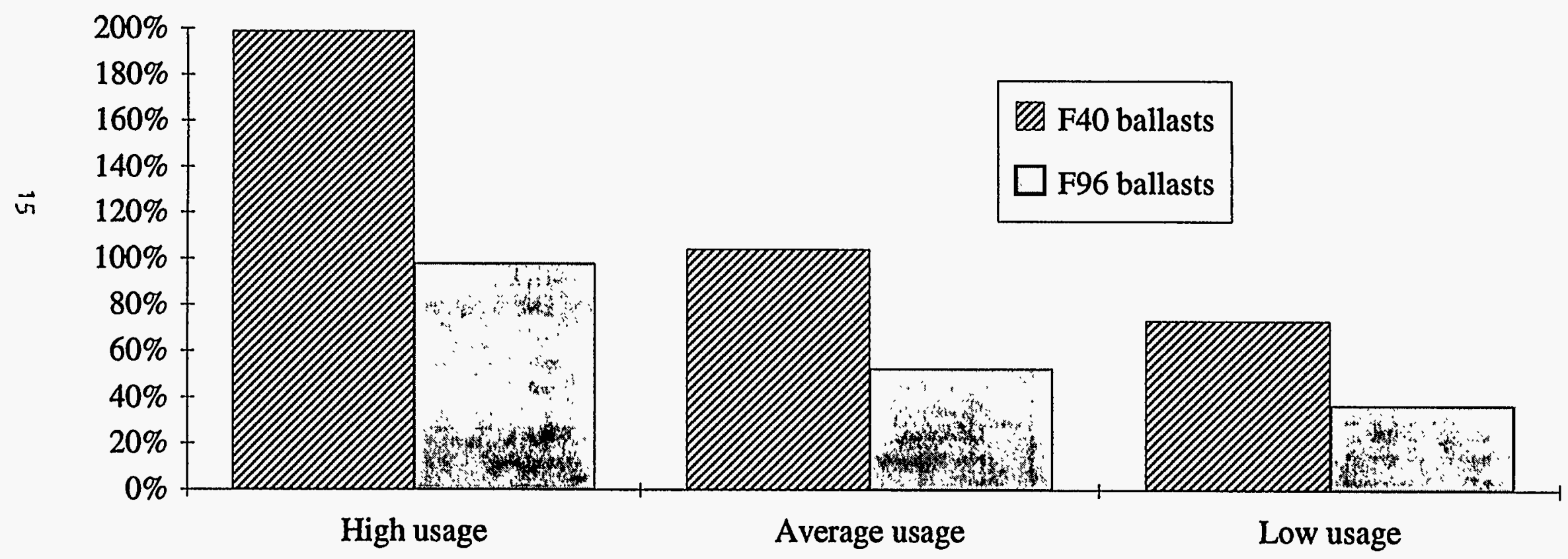




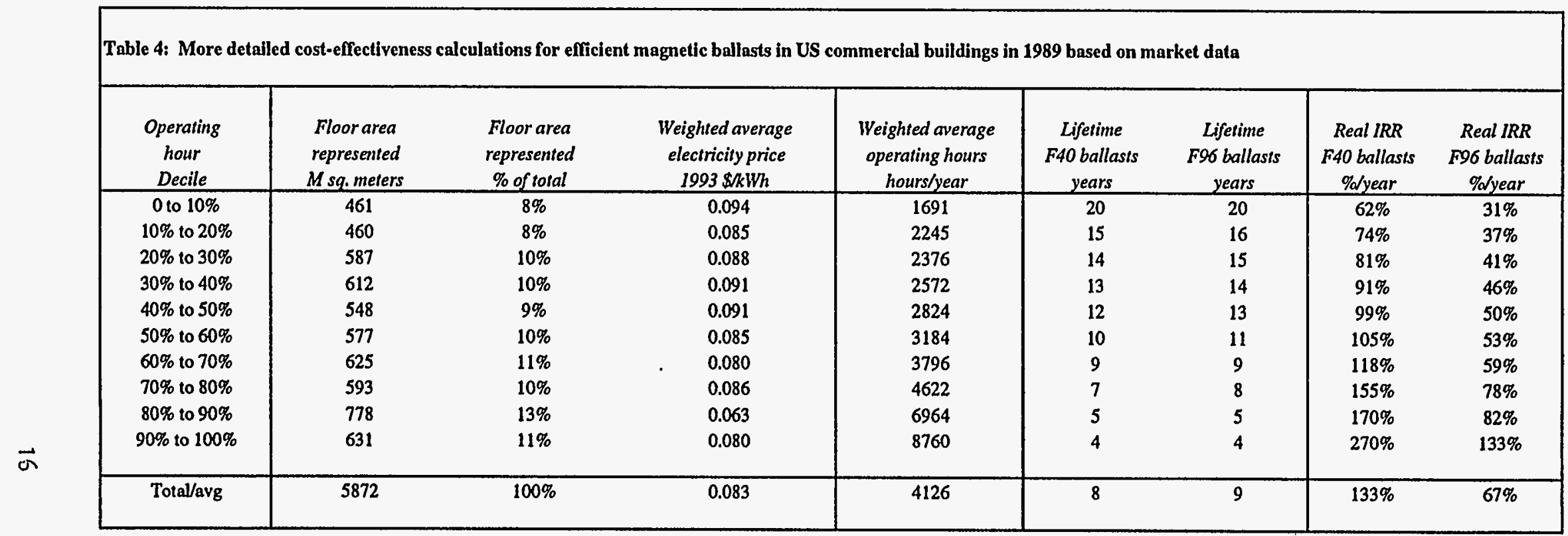

(1) Deciles are ranked in order of increasing operating hours. The $10 \%$ decile contains the $10 \%$ of the buildings in the CBECS sample (US DOE 1991a) with the lowest operating hours.

(2) All weighted averages calculated using the column titled "\% of floor area represented".

(3) IRR calculated assuming 33,000 hour lifetime for F40 ballasts and 36,000 lifetime for F96 ballasts (LRI 1995). Maximum lifetimes assumed to be 20 years.

(4) Change in costs 1989 to 1990 from Table 1, adjusted to reflect manufacturer to retail markup (see Table 2). Saturation of efficient core-coil ballasts is 35.9\% in 1989.

(5) Commercial building operating hours estimated from CBECS 1989 electronic sample (US DOE 1991a).

(6) Commercial sector electricity prices are the weighted averages across all buildings in each usage bin, taken from the CBECS 1989 electronic sample (US DOE 1991b),

and scaled downward by $10 \%$ to make the overall average reflect average 1989 prices to the US commercial sector from US DOE (1991c).

(7) Savings are $10 \mathrm{~W}$ for F40 ballasts and $15 \mathrm{~W}$ for F96 ballasts.

(8) To convert square meters to square feet, multiply by 10.76 .

(9) Sales of F40 ballasts were 77\% of total magnetic ballasts in 1990, and F96 were $23 \%$. 
This detailed analysis does not change the basic conclusions from Tables 3 and 4. Efficient magnetic ballasts represented an excellent investment for 99 percent of commercial building floor stock, and a moderately good investment for 0.7 percent of the commercial floor stock. Still, these ballasts were only being adopted in the 1980 s at a rate commensurate with the enactment of appliance efficiency standards in various states.

\section{DISCUSSION}

\section{Omitted costs}

With one exception, this particular example is free of omitted costs. The inefficient and efficient magnetic ballasts are indistinguishable except that the efficient version uses less energy, costs somewhat more to manufacture, and lasts longer. Light quality is not affected by the choice of ballast. The level of service delivered by both devices is the same.

The one cost that has been omitted from the calculations is that of finding out about the more efficient technology and changing institutional purchasing behavior. On the one hand, as argued by Jaffe and Stavins (1994), this can be considered a "normal" cost, not reflecting market imperfections. On the other, it can also be considered a transaction cost conditional on the institutional environment and therefore in principle a legitimate target of policy (Sanstad and Howarth 1994). In our view, this "cost of learning" may help to explain why this highly cost-effective technology was being adopted in the marketplace so slowly as to puzzle even the ballast manufacturers. We regard it, however, as being both policy-relevant and policy-amenable, because it is eliminated by energy-efficiency standards.

Some have argued that certain elements of risk associated with adopting the new technology should be viewed as a potential "omitted cost" as well. As we noted previously, we are not directly addressing issues of risk and uncertainty in this paper, but several attempts have been made by other researchers to argue that risk and uncertainty should lead investors to apply "hurdle rates" to energy efficiency investments that substantially exceed conventional estimates of opportunity costs of capital. However, the "rational" hurdle rates calculated in that work typically do not exceed $20 \%$. The IRRs calculated here exceed $20 \%$ real for $99 \%$ of the commercial sector floor area, which indicates that other factors than risk and uncertainty must explain the failure of virtually all consumers to adopt this technology. 13

\section{Correct parameter specification}

The parameters necessary to calculate IRR include operating hours, electricity prices, lifetimes, and incremental capital costs. Operating hours and electricity prices represent the appropriate values for each building in the CBECS sample (US DOE 1991a). Since this sample is chosen to be statistically representative, and because the electricity prices are derived from actual billing data for each building, we believe that the values derived for these parameters from CBECS accurately reflect current usage patterns and prices.

\footnotetext{
${ }^{13}$ Another important fact is that in this case the new device was based on essentially the same technology as the old, and was known to the manufacturers to be more reliable. Thus, the "objective" risk involved with adoption was minimal.
} 
The incremental capital costs are derived from market data (Table 1), so they reflect as good a measure as is currently possible of the actual costs of the efficient ballasts. The markups in Table 2 are best estimates, but there is some uncertainty in both the importance of the various distribution channels and the relevant markup for each channel. We have no reason to believe that these markups are biased in one way or another.

The IRRs calculated here are insensitive to the assumed lifetimes. If we reduce the lifetime of the lowest operating hour bin in Table 4 from 20 years to 10 years, the IRR for F96 ballasts is reduced from 31 percent to 29 percent. For the highest usage bin, reducing the lifetime from 4 years to 2 years reduces the IRR from 133 percent to 105 percent for F96 ballasts. We believe we have estimated lifetimes as accurately as is possible with current data, but even if the lifetimes were reduced by a factor of two, the results would not change substantially.

The time dynamics of the ballast costs introduces another complexity. Costs continued to decline after 1990, and the net effect of the standard was merely to delay these cost declines for a year or two.

We conclude that the important parameters for the cost effectiveness equation have been correctly specified, based on the best survey data now available. Moderate changes in any of the input parameters are unlikely to change the basic result, which is that efficient magnetic ballasts were cost effective for the overwhelming majority of commercial sector floor area.

\section{Time lags}

As we show in Figure 1 and the accompanying text, the efficient ballasts were adopted during the 1980s in direct correspondence to the state efficiency standards instituted during that period. The technology had been on the market since the mid-1970s, and the time needed to retool factories and change distribution channels is on the order of one to three years. We therefore conclude that "normal" time lags associated with the diffusion of new technology do not account for the slow adoption of efficient ballasts.

\section{Market imperfections}

The analysis we have performed here demonstrates in engineering-economic terms the value of efficient magnetic florescent ballasts in the vast majority of applications. We now return briefly to the issue of what factors might have inhibited the diffusion of this technology. As we noted at the outset, the nature of market imperfections related to energy efficiency is a topic of intense debate. Although a full discussion is beyond the scope of this paper, we quickly review several ideas arising in this context that may bear on the case of efficient ballasts.

Adverse selection, or the "lemons" problem, is one candidate to explain the slow diffusion of efficient ballasts (Akerlof 1970). In this view, improved energy efficiency is analogous to improved quality. Barriers to the transmission of information between buyers and sellers regarding the merits of efficient ballasts result in a lowering of "quality," or levels of energy efficiency, in the market for florescent lighting. This situation can arise, in part, because it is impossible for an end-user, even one who has obtained the bills, to determine the importance of various end-uses to the total bill. Submetering of particular end-uses is extremely rare. This situation is equivalent to the proverbial "supermarket without prices": the user collects all the purchases and gets one lump-sum bill to pay at the end, with no separate accounting. 
A related explanation is principal agency problems arising from the structure of the lighting market (Jaffe and Stavins 1994). Most ballasts are purchased by people who are not the ultimate end-users of the equipment, and the end-user in a new building typically has no way to determine how efficient the lighting is (this problem affects other equipment as well). In an existing building, a new tenant may or may not be able to obtain the energy bills for the space, but frequently tenants in large buildings are not separately metered. Either condition would generally result in under-investment in energy-efficiency given the higher first costs associated with the efficient ballast.

Finally, when lighting decisions are made within a firm, sub-optimal decisions on energyefficiency can arise from the manner in which intra-firm information flows and decision procedures are structured (DeCanio 1993). We believe that one such complication, the transaction and information costs of institutions changing their purchasing behavior, is particularly important for further investigation (Koomey 1990).

\section{The importance of markups}

Subtleties about pricing in particular markets are not well known. In particular, understanding the relative shares of various distribution channels and their associated markups is critical to assessing how this particular set of markets functions. Little is known about how these decisions are made, but it is likely that the markups are based on long-established "rules of thumb" that are slow to change. This area of institutional behavior is one that deserves to be investigated further.

\section{Standards and ballast prices}

Because the costs per ballast continued their decline after 1990, it is difficult to argue that the magnetic ballast standards permanently raised prices by some fixed amount. Instead, the marketplace continued to adjust markups and end-user prices in the face of rapid technological changes. In particular, competition between magnetic ballasts and the ever more cost-effective electronic ballasts, as well as competition between domestic manufacturers and low-cost foreign producers, probably caused this decline. At worst, the magnetic ballast standard delayed these cost declines by a year or two, which suggests a different result than the assumption for perpetuity of a constant incremental cost increase due to the standard.

\section{Standards and economic efficiency}

It can also be argued that the transaction costs of the consumer finding out about these efficient ballasts might have outweighed the savings or at least reduced the IRR calculated here. While this is true in the status quo case where no policy action was taken, the transaction costs that probably existed in this case are eliminated by efficiency standards. Therefore, it is appropriate to calculate the IRRs as shown above.

Given the results summarized in Tables 3 through 5, we conclude that the efficiency standards on ballasts were economically beneficial to society. We have not, of course, performed a formal cost-benefit analysis, but our calculations here strongly indicate that such an analysis would demonstrate that the standards policy meets the usual cost-benefit (Kaldor-Hicks) criterion. The IRRs calculated in this paper are so high, and they cover so much of the commercial floor stock, that the benefits to end-users who gained under the policy almost certainly exceeded the losses to those who did not.

Simple calculations of the total impacts of the standards also support the conclusion of net social benefit. These calculations indicate that the standards will save the equivalent of 
seven one-thousand Megawatt power plants by just after the turn of the century. Total annual energy savings attributable to the standards will be about 36 TWh by this time, which (at current electricity prices) would be worth about $\$ 2.5$ billion/year. Such savings dwarf the few million dollars required to implement the standards.

\section{Cost-effectiveness and policy context}

This example illustrates that a policy like efficiency standards can be effective in improving energy and economic efficiency. There were other possible ways for government and utilities to have intervened in this market, but none of the others would have yielded $100 \%$ effectiveness within a couple of years of enactment, and all of the others would have cost society more than the standards did. The standards were particularly efficacious because they were directly targeted at the consumers' transaction/search costs that impeded the adoption of the efficient ballasts. The standards eliminated those transaction costs, and did not disrupt the market in any measurable way. In addition, as the manufacturers argued in the Congressional testimony, the national standards eliminated the problems created by conflicting state standards (Freegard 1988).

\section{Implications for proposed standard requiring electronic ballasts}

It is plausible to argue that the same market imperfections inhibiting the efficient magnetic ballasts (even in the face of their high cost effectiveness) will also inhibit the penetration of electronic ballasts. The technology of electronic ballasts is fundamentally different even though the basic service delivered is the same as magnetic ballasts, so it is difficult to say a priori how much electronic ballasts will be hindered by the market imperfections afflicting magnetic ballast technology.

\section{FUTURE WORK}

\section{Usage differences between $F 40$ and F96 ballasts}

Low operating hours are the main reason why efficient ballasts are not cost-effective in certain buildings. CEC (1982) analyzed the potential savings from the proposed California standard, and estimated that F96 ballasts operated 70\% more hours ( 5000 hours/year for F96 vs. 3000 hours/year for F40). We assume usage distributions are the same for F40 and F96 ballasts, because we have no data to justify another assumption. From first principles, one would expect that the F96 ballasts (because of their higher absolute cost) would be more likely to be installed in high usage areas. If this expectation holds, it would make the efficient magnetic ballasts even more cost effective. Survey data is needed to determine whether F96 ballast usage differs from F40 ballast usage.

\section{Economies of scale and the Progress Ratio}

The costs derived in this article from market data are from a single year of data. In most manufacturing industries, however, the cost per unit of production has a strong dynamic component related to historical experience. Costs per unit typically decline by 20 to $30 \%$ every time production experience doubles (Krause et al. 1995), and this decline is characterized by what is called the "Progress Ratio". It is not clear exactly how the imposition of efficiency standards affect per unit manufacturing costs over the medium term. In particular, it is not clear if typical progress ratios can be applied to the ramping up of production of efficient magnetic ballasts, or whether the technology is so similar to that which it replaced that no such cost reductions resulted. More analysis is needed on this point. 


\section{Market data on "Who buys what devices from whom?"}

Little is known about the various distribution channels for ballasts and other lighting equipment. More research is needed on the relative differences between markups for F40 and F96 ballasts, as well as on how the distribution channels and markups are changing over time.

\section{Market imperfections}

We have demonstrated the existence of market imperfections in this paper, but have not established an iron-clad correspondence between an underinvestment in efficiency and particular market imperfections. We hypothesize that the existence of many intermediaries between the manufacturer and the end-user of the equipment will make it more likely that energy efficiency will be ignored. Another possibility is that the inability of end-users to verify the potential savings inhibits the purchase of the more efficient device. Finally, the transactions/search costs for consumers to obtain information about the more efficient device are likely to have impeded adoption of efficient magnetic ballasts. All of these areas are worthy of further exploration.

\section{CONCLUSIONS}

We have presented a methodology for identifying technical evidence of market imperfections related to energy efficiency, and applied this framework to an example of a cost-effective energy-efficient technology whose adoption in the market has been impeded. Like Galileo, we were successful in eliminating the extraneous "frictional" effects that normally afflict phenomena in our field of study.

The efficient ballasts offer consumer services identical to those provided by standard ballasts and their adoption clearly yields economic benefits. We demonstrate that market imperfections inhibited the adoption of this highly cost-effective technology. In this particular case, efficiency standards undeniably improved economic welfare and counteracted the effect of market imperfections.

\section{ACKNOWLEDGEMENTS}

We are grateful to Richard Jones of the Office of Building Technologies, US Department of Energy, for funding this work. We received helpful comments from (in alphabetical order) Carl Blumstein (UC Berkeley), Stephen DeCanio (UC Santa Barbara), Andrea Denver (LBNL), William Golove (LBNL), Hill Huntington (Energy Modeling Forum), Jim Logan (LBNL), Terry Logee (U.S. Department of Energy), Puran Mongia (LBNL), and Barbara Praetorius (Deutsches Institut fur Wirtschaftsforschung in Germany). Special thanks to Fred Berryman of the California Energy Commission for digging into his archives to find reports and other information on the California ballast standards. Thanks also to Al Gough of the Lighting Research Institute for his help in extracting and understanding the census data on ballast shipments.

This work was supported by the Assistant Secretary for Energy Efficiency and Renewable Energy, Office of Building Technologies of the U.S. Department of Energy under Contract No. DE-AC03-76SF00098. 


\section{REFERENCES}

Akerlof, G. 1970. "The Market for Lemons: Quality Uncertainty and the Market Mechanism." Quarterly Journal of Economics. vol. 89, no. 3. p. 488.

CEC. 1981. Staff Report: Fluorescent Lamp Ballasts-Summary of September 15, 1981 Workshop. California Energy Commission. P400-81-040. December.

CEC. 1982. Staff Report: Fluorescent Lamp Ballasts-Staff Analysis of Proposed Standards. California Energy Commission. P400-82-018. February.

Census, U.S. Bureau of the Census. 1994. The Statistical Abstract of the United States 1994. 114th edition Washington D.C.: U.S. Government Printing Office.

DeCanio, Stephen. 1993. "Barriers within firms to energy-efficient investments." Energy Policy. vol. 21, no. 9. p. 906.

Freegard, Ernest M. 1988. Testimony on behalf of the Lighting Equipment Division of the National Electrical Manufacturers Association. Testimony Before the Subcommittee on Energy and Power of the Committee on Energy and Commerce, House of Representatives, One Hundredth Congress, Second session. Published by the US Government Printing Office. March 23, 1988 (Published 1989).

Hassett, Kevin A., and Gilbert E. Metcalf. 1993. "Energy Conservation Investment: Do Consumers Discount the Future Correctly?" Energy Policy. vol. 21, no. 6. p. 710.

Howarth, Richard B., and Alan H. Sanstad. 1995. "Discount Rates and Energy Efficiency." Contemporary Economic Policy. vol. 13, no. 3. p. 101.

Huntington, Hillard G., Alan H. Sanstad, and Lee J. Schipper. 1994. "Editors' Introduction in Huntington, Sanstad and Schipper, Eds., Markets for Energy Efficiency, Special Issue." Energy Policy. vol. 22, no. 10. p. 795.

Jaffe, Adam B., and Robert N. Stavins. 1994. "Energy-Efficiency Investments and Public Policy." The Energy Journal. vol. 15, no. 2. p. 43.

Koomey, Jonathan. 1990. Energy Efficiency Choices in New Office Buildings: An Investigation of Market Failures and Corrective Policies. $\mathrm{PhD}$ Thesis, Energy and Resources Group, University of California, Berkeley.

Koomey, Jonathan, Celina Atkinson, Alan Meier, James E. McMahon, Stan Boghosian, Barbara Atkinson, Isaac Turiel, Mark D. Levine, Bruce Nordman, and Peter Chan. 1991. The Potential for Electricity Efficiency Improvements in the U.S. Residential Sector. Lawrence Berkeley Laboratory. LBL-30477. July.

Koomey, Jonathan, and Alan H. Sanstad. 1994. "Technical Evidence for Assessing the Performance of Markets Affecting Energy Efficiency." Energy Policy. vol. 22, no. 10. p. 826.

Koomey, Jonathan G., Mary Ann Piette, Mike Cramer, and Joe Eto. 1995. Efficiency Improvements in U.S. Office Equipment: Expected Policy Impacts and Uncertainties. Lawrence Berkeley Laboratory. LBL-37383. December.

Krause, Florentin, Jonathan Koomey, and David Olivier. 1995. Energy Policy in the Greenhouse. Volume II, Part 3D. Renewable Power: The Cost and Potential of Low-Carbon Resource Options in Western Europe. El Cerrito, CA: International Project for Sustainable Energy Paths. 
Logan, James. 1995. Personal Communication: "Discussion regarding markups in the fluorescent ballast market". Lawrence Berkeley National Laboratory. July.

LRI. 1995a. Research on the Fluorescent Lighting Market for Lawrence Berkeley Laboratory's Energy Analysis Program. Lighting Research Institute. A. Gough, LRI Principal Investigator; J. Burke, Burke and Associates subcontractor to LRI, under LBL Subcontract No. 4602810.

LRI. 1995b. Surveys of ballast manufacturers, luminaire manufacturers, and lighting management companies performed and aggregated by Lighting Research Institute for the Lawrence Berkeley Laboratory's Energy Analysis Program. Lighting Research Institute. A. Gough, LRI Principal Investigator; J. Burke, Burke and Associates subcontractor to LRI, under LBL Subcontract No. 4602810.

Metcalf, Gilbert E. 1994. "Economics and rational conservation policy." Energy Policy. vol. 22, no. 10. p. 819.

Metcalf, Gilbert E., and Donald Rosenthal. 1993. Green Lights and Cold Refrigerators: An Analysis of Optimal Energy Conservation Policy in an Uncertain World. Princeton University. unpublished manuscript. December.

Nichols, Albert L. 1994. "Demand-side management: Overcoming market barriers or obscuring real costs?" Energy Policy. vol. 22, no. 10. p. 840.

Sanstad, Alan H., Carl Blumstein, and Steven E. Stoft. 1995. "How High are Option Values in Energy-Efficiency Investments?" Energy Policy. vol. 23, no. 9. p. 739.

Sanstad, Alan H., and Richard Howarth. 1994. "Normal' Markets, Market Imperfections, and Energy Efficiency." Energy Policy. vol. 22, no. 10. p. 826.

Stoft, Steven. 1993. "Appliance Standards and the Welfare of Poor Families." The Energy Journal. vol. 14, no. 4. p. 123.

Sutherland, Ronald J. 1991. "Market Barriers to Energy-Efficiency Investments." The Energy Journal. vol. 12, no. 3. p. 15.

US DOE. 1989. Annual Energy Outlook: Long-Term Projections 1989. Energy Information Administration, U.S. Department of Energy. DOE/EIA-0383(89).

US DOE. 1991a. Commercial Buildings Energy Consumption Survey: Commercial Buildings Characteristics 1989. Energy Information Administration, U.S. Department of Energy. DOE/EIA-0246(89). June.

US DOE. 1991b. Commercial Buildings Energy Consumption Survey: Consumption and Expenditures 1989. Energy Information Administration, U.S. Department of Energy. DOE/EIA-0318(89). April.

US DOE. 1991c. State Energy Price and Expenditure Report 1989. Energy Information Administration, U.S. Department of Energy. DOE/EIA-0376(89). September.

US DOE. 1995. Annual Energy Outlook 1995, with Projections to 2010. Energy Information Administration, U.S. Department of Energy. DOE/EIA-0383(95). January. 


\section{APPENDIX A: DERIVING STATE MARKET SHARES}

We derive market shares for ballasts using the approximations detailed in Table A-1. We distinguish between new additions to the commercial stock and existing commercial stock. The top part of Table A-1 calculates the average ballast market share for new and existing buildings over the 1985 to 1993 period. It uses existing stock floor area from Koomey et al. (1995) and US DOE (1995) with an eight year lifetime (the average from Table 4) to estimate the amount of the floor area retrofitted each year. It uses new floor area additions from Census (1994). These two numbers are calculated each year from 1985 to 1993 as a fraction of total, and then the simple average is calculated for use in the bottom of the table.

The available state data was the value of construction contracts in 1993 (which represents new construction) and population (which is a reasonable proxy for existing stock). Both are taken from Census (1994). The distributions by state are comparable. We weight the two distributions by the fractions derived in the top of the table to get a weighted average share of ballast sales by state. We then correct those shares to reflect the fact that California had a 20 percent saturation of efficient ballasts in 1980 (CEC 1982) and that the saturation for the US as a whole was $12.5 \%$. This calculation implies that all states but California had (on average) an $11.5 \%$ share of efficient magnetic ballasts. 
Table A-1: Derivation of ballast market shares attributable to each state that implemented standards

\begin{tabular}{|c|c|c|c|c|c|c|c|}
\hline & $\begin{array}{c}\text { Existing } \\
\text { Commercial } \\
\text { Floor stock } \\
\text { Billion sq. ft. }\end{array}$ & $\begin{array}{c}\begin{array}{c}\text { New floor area } \\
\text { built } \\
\text { Billion sq. } f \text {. }\end{array} \\
\end{array}$ & $\begin{array}{l}\text { Existing floor } \\
\text { stock retrofitted } \\
\text { assuming } 8 \text { yr } \\
\text { lighting lifetime } \\
\text { Billion sg. ft. }\end{array}$ & $\begin{array}{c}\text { Total } \\
\text { new + retrofitted } \\
\text { floor area } \\
\text { Billion sq. ft. }\end{array}$ & $\begin{array}{c}\text { New floor area } \\
\text { built } \\
\% \\
\end{array}$ & $\begin{array}{c}\text { Existing floor } \\
\text { stock retrofitted } \\
\text { assuming } 8 \text { yr } \\
\text { lighting lifetime } \\
\%\end{array}$ & $\begin{array}{c}\text { Total } \\
\text { new + retrofitted } \\
\text { floor area } \\
\% \\
\end{array}$ \\
\hline 1985 & 56.6 & 1.5 & 71 & 8.6 & $18 \%$ & $82 \%$ & $100 \%$ \\
\hline 1986 & 58.2 & 1.5 & 7.3 & 8.7 & $17 \%$ & $83 \%$ & $100 \%$ \\
\hline 1987 & 59.9 & 1.5 & 7.5 & 9.0 & $16 \%$ & $84 \%$ & $100 \%$ \\
\hline 1988 & 61.5 & 1.4 & 7.7 & 9.1 & $16 \%$ & $84 \%$ & $100 \%$ \\
\hline 1989 & 63.2 & 1.4 & 7.9 & 9.3 & $15 \%$ & $85 \%$ & $100 \%$ \\
\hline 1990 & 64.3 & 1.2 & 8.0 & 9.2 & $13 \%$ & $87 \%$ & $100 \%$ \\
\hline 1991 & 65.2 & 1.0 & 8.2 & 9.1 & $11 \%$ & $89 \%$ & $100 \%$ \\
\hline 1992 & 66.1 & 0.9 & 8.3 & 9.2 & $10 \%$ & $90 \%$ & $100 \%$ \\
\hline 1993 & 67.0 & 1.0 & 8.4 & 9.3 & $10 \%$ & $90 \%$ & $100 \%$ \\
\hline \multirow[t]{2}{*}{ Avg 1985-93 } & & & & & $14 \%$ & $86 \%$ & $100 \%$ \\
\hline & $\begin{array}{l}\text { Non Res. } \\
\text { Construction } \\
\text { contracts } \\
1993 \\
\end{array}$ & $\begin{array}{c}\text { Population } \\
\text { percentages } \\
\text { Avg 1985-89 } \\
\end{array}$ & $\begin{array}{c}\text { Weighted average } \\
\text { state ballast } \\
\text { market shares }\end{array}$ & $\begin{array}{l}\text { Wtd avg state } \\
\text { ballast shares } \\
\text { adjusted to reflect } \\
1980 \text { saturation }\end{array}$ & & & \\
\hline \multirow{7}{*}{$\begin{array}{c}\mathrm{CA} \\
\mathrm{FL} \\
\mathrm{MA} \\
\mathrm{NY} \\
\mathrm{CT} \\
\text { Total US }\end{array}$} & $11.9 \%$ & $11.5 \%$ & $11.5 \%$ & $9.2 \%$ & & & \\
\hline & $5.7 \%$ & $4.9 \%$ & $5.1 \%$ & $4.5 \%$ & & & \\
\hline & $2.5 \%$ & $2.5 \%$ & $2.5 \%$ & $2.2 \%$ & & & \\
\hline & $6.1 \%$ & $7.4 \%$ & $7.2 \%$ & $6.4 \%$ & & & \\
\hline & $1.2 \%$ & $1.3 \%$ & $1.3 \%$ & $1.2 \%$ & & & \\
\hline & $100 \%$ & $100 \%$ & $100 \%$ & & & & \\
\hline & $\begin{array}{c}\text { New fraction } \\
0.14\end{array}$ & $\begin{array}{c}\text { Existing fraction } \\
0.86\end{array}$ & & & & & \\
\hline
\end{tabular}

(1) Existing floor stock 1985-89 taken from Koomey et al. 1995. Existing floor stock 1990-93 taken from US DOE 1995.

(2) New floor area taken from Census 1994, p.728, Table 1198.

(3) Non-residential construction contracts by state in 1993 taken from Census 1994, p.728, Table 1199.

(4) Population percentages by state (averaged 1985-89) taken from Census 1994, p.27, Table 26.

(5) Lighting lifetime assumed to be 8 years, with 1/8 of existing floor stock retrofitted each year.

(6) State ballast market shares derived by weighting percentages of construction contracts and population by state by the fraction of the ballast market attributable to new construction and existing retrofits, respectively.

(7) State market shares adjusted to reflect 1980 saturation of 20\% for efficient magnetic ballasts in CA (CEC 1982) and 11.5\% shares elsewhere. Weighting these by their respective sales fractions results in the average $12.5 \%$ saturation level for the US in 1980. 


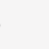

